\title{
PATENT PROTECTION OF THE INTELLECTUAL PROPERTY - TECHNOLOGY FIELDS AND INDUSTRY ANALYSIS
}

\author{
Monika Walicka \\ Department of Finance and Accountong, Faculty of Management, Bialystok University of Technology, \\ Ojca Tarasiuka 2 Street, 16-001 Kleosin, Poland \\ E-mail:m.walicka@pb.edu.pl
}

\begin{abstract}
In this paper the industry and top patent applicants was studied from perspective of 4 types of intellectual property (IP) and 3 patent systems. The purpose of this study was to map world patents applications. World Intellectual Property Organization (WIPO) data base was used. Results show that there is a growing trend in three analyzed patent systems and patents applications span a wide range of technologies. Under PCT procedures three leading fields of technologies: Electrical machinery, Computer technologies, and Medical technologies was found. Trademark applications are focused on Research and Technology and Agriculture sector, Industrial design on Textiles and accessories.
\end{abstract}

Keywords: patents, intellectual property, PCT.

JEL Classification: L50; K11.

\section{Introduction}

Patents are often used as an indicator of growth of science and development (Archibugi 1992). In this article the patent is defned as a right exclusively granted for an invention (Simonton 2012; CzemielGrzybowska, Skowronek-Mielczarek 2015) but also it is a scientific description of an invention which is not disclosed elsewhere later (van Zeebroeck et al. 2005). A patent grants an authorized person the right to exclude others from making, using, offering for sale or importing products or processes based on the invention; and in this way it forbids other entities to carry out such activities without a prior consent of a patent holder. A patent is an important tool used by enterprises in their economic activity, e.g. in order to achieve competitive advantage, increase own reputation and goodwill and gain additional profit, e.g. from licenses granted for using an invention (Squicciarini et al. 2013; Czemiel-Grzybowska 2013; Wu, Liu 2006).

The majority of legislative systems are based on a definition of requirements that should be met by an invention subject to patenting. Patents are granted for technological solutions which are new, involve an inventive step and are capable of industrial application (Johnson 2015). An invention may be a new device, product, method, process or significant modernization of the already existing solutions (Agrawal et al. 2015).

List (2010) stated that patents have long been known as a usefull source of information. In this article are used WIPO indicators of IP to assess the industries in a given country or area that are interested in IP protection. The aim of this study is to map the past and current trends in patenting activities with a view to better understanding its changing nature. We used research methods based on Noruzi and Abdekhoda (2012) conducted in Iran in 2011. Patent mapping is a usful method to give general picture of technologies development. The purpose of this study is to map world patents registered in WIPO during 2014 based on PCT, MITS and HIDS annual data. The patenting activity was investigated for the period 2011-2014, based on the WIPO Data Base. The collected data were analyzed applying Microsoft Excel.

\section{Patents and utility models, trademarks and industrial designs patent protection - general requirements}

In accordance with the applicable provisions of the law, a few patent procedures may be identified. The European Union uses the European Patent Procedure (EPP). The procedure of granting European patents occurs in stages. It is characteristic that it is possible to be granted a patent simultaneously in all the countries being the parties to the Convention on the Grant of European Patents, upon filing a patent application at the European Patent Office (EPO) in Munich and upon unified application proceedings. The application is directly 
filed to the EPO in one of its official languages. The applicant must indicate the countries in which patent protection will be ensured. The following stages include: formal examination and patent search finished with publishing an announcement about the application and search results. An application should include: a description of the invention, one or more patent claims, drawings used in the description or claims, an abstract and an application for the European patent. The application may have other documents attached, e.g. a power of attorney, a priority document, a document indicating the inventor, a proof of fee payment, a disk including a list of sequences. All formal requirements of an application, including the information about constructing a description, patent claims, an abstract and drawings are included in the Implementing Regulations of the EPC.

Upon the examination procedure of patent potential of an invention, the EPO agrees with the applicant on the final version of the application. An applicant delivers translation of claims into other official languages of the EPO, makes a payment of the patent fee and printing of the description. Then, the EPO takes a decision on granting a patent and publishes the description in the EPO bulletin. In the period of 9 months following the date of publishing, an opposition may be expressed against the granted patent (Walicka et al. 2015). It opens an opposition procedure which may result in overruling the EPO's decision on granting a European patent. An applicant may appeal against the decision ending the application proceedings or opposition proceedings to the Board of Appeal of the EPO. A European patent is binding in the selected countries provided that the applicant delivers translation of the patent description into the official languages of these countries (Lisbon agreement 1958). Granting a European patent ensures identical protection as in the case of patents granted on the basis of the national procedures.

The Patent Cooperation Treaty (PCT) is a procedure slightly different from the EPP. It is a process of obtaining protection for an invention on the basis of one patent application specified in the provisions of the Patent Protection Treaty. PCT supports applicants' inventions in patent protection on international level and also assist national patent offices with patent granting decisions. Patent applicants by filing the PCT international patent application can apply for invention protection simultaneously in 148 countries on the world.

An application under the PCT, described as an international application, is filed at the so-called receiving office (Leydesdorff, Meyer 2010). An application shall include: a request for grant, a description, claims, drawings, an abstract of the description and it shall be made in one of the official languages of the International Searching Authority. The request should mention the countries that will ensure patent protection. The receiving office keeps one copy of the application package, the second copy is delivered to the International Office in Geneva and the third one - used in the search phase - is sent to the EPO. The international publication of the application appears immediately upon 18 months following the date of priority or -upon the applicant's request - earlier, upon 12 months. An applicant may commission chargeable international preliminary examination whose objective is to form a preliminary and non-binding opinion on the patent potential of the invention. Such an opinion usually influences decisions made by patent offices in the countries providing patent protection, which receive patent applications upon the end of the international phase of the PCT proceedings. The national PCT phase comprises filing a patent application in local patent offices in the countries of desired protection in the period not exceeding 30 months following the date of priority, formal and subject matter examination of the solution by these offices and decisions granting a patent or patent refusal. The PCT mode is favourable to the applicant in many ways (Agrawal et al. 2015). Designating countries of desired protection only requires ticking an adequate box in the form (Walicka 2014). Furthermore, in the period of priority that lasts 12 months only one application is filed and the documentation is prepared in one language only once. When the number of countries ensuring patent protection is higher, costs of the PCT proceedings are lower than the sum of costs of the national proceedings. The most favorable element of the PCT procedure is delaying the moment of the applicant's decision about entering the national phase up to 30 months following the priority date. During this time, the applicant may inspect the value of the solution also on the basis of international preliminary studies. The applicant can resign from applying for protection in at least some countries. Apart from the above mentioned forms of applying for patent protection, there is also a possibility to undergo the EURO-PCT procedure, which combines the European procedure and the PCT procedure. In this mode, the PCT comprises the regional phase instead of the national phase. An international application is sent upon the international phase to the EPO and examined pursuant to the European procedure, which is ended with granting a European patent in the countries of the 
Convention on the Grant of European Patents (Rodriguez, Gomez 2011).

Using an invention for professional or remuneration purposes by other entities without the consent of the person authorized by the patent is, with some exceptions, a breach of the substantive law. It entails sanctions in the form of civil and/or criminal liability. Claims connected with a breach of patent can be asserted in common courts. Each patent procedure applied nowadays provides for disclosure of the essence of the solution by publishing information about the patent application. Knowledge about functioning of the invention is widely available. In exchange for disclosure of the invention's essence, the inventor is guaranteed legal protection by the international community.

Patent protection generates some costs (Scellato et al. 2011):

- administration fees incurred by an applicant during all stages of the application procedure;

- patent renewals (the twenty-year period of patent protection is divided into shorter, at least one-year protection periods which are chargeable);

- costs of legal representation during the application process and protection period (services provided by patent attorneys).

In the case when patent protection of an invention is unprofitable, the authorized person can resign from upholding own right, e.g. by resignation from paying the fee for the next protection period. Each country individually settles administration fees for application procedures and maintaining the patent. Costs of patent protection increase because of translation costs - granting a patent is connected with translating the application to official languages of the countries providing future protection (Schultz et al. 2012). The procedure of granting a European patent is divided into stages.

The stage of search is separated from substantive examination. This gives an applicant a choice whether to continue and undergo substantive examination, and as a result to incur further costs connected with obtaining patent protection, on the basis of a search report and an opinion concerning patent potential. The procedure of granting European patents is a research procedure that begins with formal examination and compulsory European search. A search report is drawn up on the basis of patent claims, taking a description and drawings into account. A report enumerates documents available at the European Patent Office at the moment of drawing up the report. The documents might be taken into account when assessing novelty and the fact of involving an inventive step. Upon preparation of a search report, it is sent immediately to the applicant together with copies of documents that are cited in the report and a written opinion about the patent potential, which is prepared on the basis of the search report. The second part of the procedure (substantive examination) is started upon the applicant's request and comprises full investigation and granting a patent. Upon filing an application for examination and paying the fees, the second stage is substantive examination (full investigation). Its objective is to verify if an invention meets all the requirements of the Convention on the Grant of European Patents concerning patent potential, i.e. if it meets the requirements specified in Article 52 of the EPC 2000: "European patents shall be granted for any inventions, in all fields of technology, provided that they are new, involve an inventive step and are susceptible of industrial application." If the European Patent Office decides that the application and the invention both meet the requirements of the Convention, it grants a patent. An applicant must pay the fee for granting a patent, including the fee for printing the patent description.

Madrid - The International Trademark System (MITS) was established under the Madrid Agreement (WIPO 1891) and the Madrid Protocol (WIPO 1989). MITS is a one-stop solution for registering and managing marks worldwide administered by WIPO. Madrid System allows applicants to file one application, in one language, and pay one set of fees to protect the mark. Is simplifies the process of worldwide trademarks registration and general management of the mark. Registration through MITS not create international trademark, but the final decision of acceptance/rejection of the trademark is given by each national or regional office. MITS covers the territories of up to 97 members.

Hague System for the International Registration of Industrial Design (HIDS) was established basis on the London Act of 1934 (The Hague agreement... 1925a), the Hague Act of 1960 (The Hague agreement... 1960) and the Geneva Act of 1999 (Regulations under... 1998). HIDS provides applicants a practical business solution for registering up to 100 industrial designs in over 65 territories. It is possible by filing one international application with the International Bureau of WIPO. It let to simplify the industrial design management through single procedures (Bhattacharya 2007). 


\section{Data description and methodology design}

Research data was collected from Statistics Database of World Intellectual Property Organization (WIPO). WIPO database is the biggest raw data set tool where data is collected directly from offices through a set of questionnaires each year. Two time periods data was used: 2011-2012 and 20132014 for global applications growth analyze and 2014 for regional and cross-industry analyze. WIPO database includes data of total worldwide applications that are collected from national and regional IP offices, generated by applicants through filing documents and by WIPO registration systems. In addition, WIPO collect the data compiled from the PATSTAT database. The data comes from two sources: Annual IP Data Survey and direct application process of international filings through the PCT, MITS and HIDS.

In this paper the data reported and presented is based on the three concepts:

i) Applications type: patent and utility model, trademark, industrial design;

ii) Residence area: used to categorize data by residence: resident (domestic) and nonresident (foreign) ${ }^{1}$, the first inventor who recorded application in the IP document is used to classify data by country of origin;

iii) Top technology fields and industry sectors: IPC-technology concordance table was used to convert IPC symbols into 35 corresponding fields of technology (WIPO 2011), complete list of the 45 class definitions (MITS and HIDS), refer to the International Classification of Goods and Services under the Nice Agreement (1957);

iv) Top applicants: the companies that submit the biggest numbers of patent applications.

For some indicators, it was provided grouping totals by geographical regions, using the UN classification of regions.

Patend data analysis method previously was used by many researches from different perspectives on the country-group (Rodriguez, Gomez 2011); country level (Noruzi, Abdekhoda 2012; Archambault 2001). Bhattachatya (2007) used patent data base to study institutions in India and China. Chen et al. (2005) suggest that patent anal-

\footnotetext{
${ }^{1}$ WIPO's definition of resident refers to an application filed by an applicant at its national IP office, bur a non-resident refers to application filed at a foreign IP office, e.g. application filed by Japan resident at the Japan IP office is considered in research as "resident", an application filed at the China IP office by an French applicant is considered a non-resident for China office data. On the same regulations is based also the data of IP grant (registration).
}

ysis is a usful tool core technologies and industry research.

The data was analyzed in three steps. First, world general statistics for 4 application types was in 2011-2014 was researched to find the recent trends. Next, geographical and industry areas was alalyzed in 2014 year. Finally, we aimed the main world actors (top ten PCT, MITS and HIDS) as patent applicants.

\section{Research results}

\subsection{Intellectual property applications and active IP rights - world general statistics}

The number of patents from a country level view reveals its technology innovation performance (Noruzi, Abdekhoda 2012).

As we can see in Table 1 during the period 2011-2014 total number of patents filling tends to grow. We can see the activity for patents grew $9,3 \%$ in 2012 and $4,5 \%$ in 2014 and trademarks grew in both periods $6 \%$. Applications for utility models and industrial designs decreased in 2014 the first time in over a decade (WIPO 2015). Number of utility model applications increased on 2012, but suddenly decreased by $3 \%$ in 2014 . Industrial design in 2014, filing activity fell by $8,1 \%$ from 2012 , when it was $17 \%$.

The share of applications filled by residents in 2014 year among different forms of IP is bigger for industrial design $-84 \%$ and utility model $-98 \%$ (Table 2).

When we compare the applicants domiciled in the jurisdiction (residents) and located outside (non-residents) we can say that globally the residents file the majority of all type of applications. Among diffrent forms of IP, non-residents filled the mos patent applications for patents $(32 \%)$ and trademarks (24\%).

Next step of the research was finding current trends from geographical level. Patent classification analysis should not only provide a better knowledge of current patent trends of a country but support the distribution of those values acrosse the different geographical areas (Chen et al. 2005).

Table 3 presents the distribution of IP filing activity for each IP right. When we compare the world's six geographical regions we can see that the most of all filing activity is situated in Asia. This region received the highest numbers of all applications as: patents $(60 \%)$, utility models $(94 \%)$, trademarks $(51,8 \%)$ and industrial designs $(67 \%)$. In contrast, we can see that the lower shares of patent applications was received by offices in 
Table 1. Total applications of global intellectual property applications and active IP rights 2012-2014 by application type worldwide (Source: WIPO Statistics Database, May 2014; WIPO Statistics Database, October 2015)

\begin{tabular}{l|c|c|c|c|c|c}
\hline \multicolumn{1}{c|}{ Applications type } & \multicolumn{7}{c}{ Year } \\
\hline & 2011 & 2012 & Growth (\%) & 2013 & 2014 & Growth (\%) \\
\hline Patent & 2149000 & 2347732 & 9,2 & 2565000 & 2681000 & 4,5 \\
\hline Utility Model & 670692 & 827489 & 23,4 & 978000 & 949000 & -3 \\
\hline Trademark* & 6205368 & 6576559 & 6 & 7028000 & 7449000 & 6 \\
\hline Industrial Design** & 1040034 & 1216726 & 17 & 1238000 & 1138000 & 8,1 \\
\hline Total & 10065094 & 10968506 & & 11809000 & 12217000 & \\
\hline
\end{tabular}

Note: *refers to class count - the total number of goods and services classes specified in trademark applications, **refers to design count - the total number of designs contained in industrial design applications.

Table 2. Resident and non-resident share of total aplication in 2014 (Source: WIPO Statistics Database, October 2015)

\begin{tabular}{l|c|c|c|c|c}
\hline \multicolumn{1}{c|}{ Applications type } & Resident & Non-resident & Total & $\begin{array}{c}\text { Resident share } \\
(\%)\end{array}$ & $\begin{array}{c}\text { Non-resident share } \\
(\mathbf{\%})\end{array}$ \\
\hline Patent & 1800300 & 880600 & 2680900 & 67,2 & 32,8 \\
\hline Trademark* & 5647278 & 1802116 & 7449394 & 75,8 & 24,2 \\
\hline Industrial Design** & 961514 & 176891 & 1138400 & 84,5 & 15,5 \\
\hline Utility Model & 931700 & 17200 & 948900 & 98,2 & 1,8 \\
\hline Total & 9340792 & 2876807 & 12217594 & & \\
\hline
\end{tabular}

Note: *refers to class count - the total number of goods and services classes specified in trademark applications

**refers to design count - the total number of designs contained in industrial design applications.

Table 3. Patents, utility models, trademarks and industrial designs shares by region*** in year 2014 (Source: WIPO Statistics Database, October 2015)

\begin{tabular}{|c|c|c|c|c|}
\hline \multirow[b]{2}{*}{ Geographical region } & \multicolumn{2}{|c|}{ Patent } & \multicolumn{2}{|c|}{ Utility Model } \\
\hline & Applications & Share of total $(\%)$ & Applications & Share of total $(\%)$ \\
\hline Africa & 14900 & 0,6 & 175 & 0,02 \\
\hline Asia & 1607500 & 60,0 & 893276 & 94,1 \\
\hline Europe & 346200 & 12,9 & 49640 & 5,2 \\
\hline Latin America \& the Caribbean & 64100 & 2,4 & 4282 & 0,5 \\
\hline North America & 614300 & 22,9 & 1523 & 0,2 \\
\hline \multirow[b]{3}{*}{ Geographical region } & 33900 & 1,3 & & \\
\hline & \multicolumn{2}{|c|}{ Trademark* } & \multicolumn{2}{|c|}{ Industrial Design** } \\
\hline & Applications & Share of total (\%) & Applications & Share of total (\%) \\
\hline Africa & 207017 & 2,8 & 17300 & 1,5 \\
\hline Asia & 3855689 & 51,8 & 764600 & 67,2 \\
\hline Europe & 1982973 & 26,6 & 290000 & 25,5 \\
\hline Latin America \& the Caribbean & 626168 & 8,4 & 15600 & 1,4 \\
\hline North America & 617439 & 8,3 & 41100 & 3,6 \\
\hline Oceania & 160108 & 2,1 & 9800 & 0,9 \\
\hline
\end{tabular}

Note: *refers to class count - the total number of goods and services classes specified in trademark applications.

**refers to design count - the total number of designs contained in industrial design applications.

*** the numbers of applications of each form of IP are estimated for the offices in each region for which data are missing and, when totaled, are represented as percentages of WIPO-estimated world totals. Regions are defined by the United Nations (UN), available at: unstats.un.org/unsd/ methods/m49/m49regin.htm 
Table 4. Trends in PCT, MITS and HIDS international applications years 2005-2014 (Source: WIPO Statistics Database, October 2015)

\begin{tabular}{c|c|c|c|c|c|c}
\hline $\begin{array}{c}\text { Application } \\
\text { year }\end{array}$ & $\begin{array}{c}\text { PCT } \\
\text { applications }\end{array}$ & $\begin{array}{c}\text { Growth rate } \\
(\%)\end{array}$ & $\begin{array}{c}\text { MITS } \\
\text { applications }\end{array}$ & $\begin{array}{c}\text { Growth rate } \\
(\%)\end{array}$ & $\begin{array}{c}\text { HIDS } \\
\text { applications }\end{array}$ & $\begin{array}{c}\text { Growth rate } \\
(\%)\end{array}$ \\
\hline 2005 & 136751 & 11,5 & 33593 & 14,0 & 1194 & $-13,6$ \\
\hline 2006 & 149643 & 9,4 & 36499 & 8,7 & 1113 & $-6,8$ \\
\hline 2007 & 159933 & 6,9 & 39966 & 9,5 & 1171 & 5,2 \\
\hline 2008 & 163241 & 2,1 & 42074 & 5,3 & 1716 & 46,5 \\
\hline 2009 & 155402 & $-4,8$ & 35194 & $-16,4$ & 1798 & 4,8 \\
\hline 2010 & 164341 & 5,8 & 39687 & 12,8 & 2385 & 32,6 \\
\hline 2011 & 182437 & 11,0 & 42270 & 6,5 & 2521 & 5,7 \\
\hline 2012 & 195335 & 7,1 & 44018 & 4,1 & 2604 & 3,3 \\
\hline 2013 & 205290 & 5,1 & 46829 & 6,4 & 2990 & 14,8 \\
\hline 2014 & 214318 & 4,4 & 47885 & 2,3 & 2924 & $-2,2$ \\
\hline
\end{tabular}

Europe (12,9\%) and North America (22,9\%). On the other hand, there is in Europe relatively high level of filing activity in the case of trademarks $(26 \%)$ and industrial designs (25\%). In North America applicants did not fill many utility model applications, as generally they do not offer this IP right.

Finally, we show the last decade trends in three patent systems: PCT, MITS and HIDS. Table 4 shows growing trend of international applications. PCT system makes patenting procedures more simply by reducing the requirements to file separate application in each protection country. Growth rate for PCT and MITS is very low in 2009 but this fact is coincided with economic downturn. Then both systems continued upword trend. The Hague system let applicant to obtain protection for up to 100 industrial designs in different jurisdictions filling one application form. Number of this type applications fillings fell in $2014(-2,2 \%)$. It was the first decrease during the last 7 years of growth.

\subsection{Industry sectors}

In this chapter we analyze all type of IP applications by the prism of main fields of technologies. We find 5 top IP offices: China, EPO, Japan, Republic Korea and USA those in the period 20112014 received the most patent applications from technology fields. We found 6 top technology fields for 5 top offices:

- Electrical machinery, apparatus and energy (EM),

- Computer technology (CT),

- Digital communication (DC),

- Medical technology (MT),

- Optics (O),

- Semiconductors (S).
As a result of patent application in the field of technology International Patent Classification (IPC) symbols was used. At top offices (China, EPO, Japan, Republic of Korea) the field of EM and CT (USA) are most applicable. Medical technologies' patent application is popular among EPO and USA procedures. In Japan we can observe higher shares of applications in the field of optics.

We use Nice Classification (NC) for trademark applications by industry sectors analyze under MITS system. NC classified industry into 10 sectors. Table 5 shows the industry sectors in which applicants filed for trademark protection. Table 5 presents the data for five offices reporting the highest trademark filing activity in 2014: China, Japan, OHM, Russian Federation, USA. As a result the most attractive sector under MITS prodecures was found:

- Research \& technology (RT),

- Agriculture (A),

- Leisure \& Education (LE),

- Business (B),

- Clothing (C).

The top industry sectors at Japan, OHIM and USA was RT and LE. In China and Russian Federation top industry applications comes from A, C and RT.

Distribution of application design under HIDS procedures group 12 industry sectors. We also found top 5 offices that received the bigger number of applications: Australia, Germany, India, OHIM and Turkey. Table 5 shows that the designer filled applications only in a few sectors:

- Textiles and accessories (TE),

- Furniture and households (FH),

- Tools and machines (TM),

- Transport (T),

- Advertising (A). 
Table 5. Published PCT, MITS and HIDS applications by top technology fields and industry sectors by share of total applications in 2014 (Source: EPO PATSTAT database, October 2015; WIPO Statistics Database, October 2015)

\begin{tabular}{|c|c|c|c|c|c|c|c|c|}
\hline Office & Field of technology & PCT & Office & Industry sector & MITS & Office & Industry sector & HIDS \\
\hline \multirow{3}{*}{$\stackrel{\stackrel{\Xi}{\Xi}}{\Xi}$} & $\begin{array}{l}\text { Electrical machinery, } \\
\text { apparatus, energy }\end{array}$ & 7,6 & \multirow{3}{*}{ 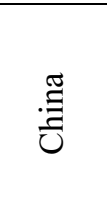 } & $\begin{array}{l}\text { Research \& } \\
\text { Technology }\end{array}$ & 11,8 & \multirow{3}{*}{ 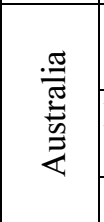 } & Tools and machines & 14,0 \\
\hline & Computer technology & 6,3 & & Clothing & 17,2 & & $\begin{array}{l}\text { Furniture and household } \\
\text { goods }\end{array}$ & 15,2 \\
\hline & Digital communication & 6,1 & & Agriculture & 21,0 & & Textiles and accessories & 15,5 \\
\hline \multirow{3}{*}{ 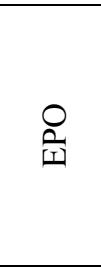 } & $\begin{array}{l}\text { Electrical machinery, } \\
\text { energy }\end{array}$ & 7,1 & \multirow{3}{*}{$\begin{array}{l}\text { Еี } \\
\text { స్ }\end{array}$} & $\begin{array}{l}\text { Leisure \& } \\
\text { Education }\end{array}$ & 14,2 & \multirow{3}{*}{ 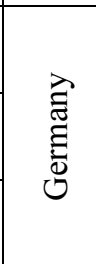 } & Advertising & 14,7 \\
\hline & Medical technology & 6,6 & & Agriculture & 14,3 & & $\begin{array}{l}\text { Furniture and household } \\
\text { goods }\end{array}$ & 19,4 \\
\hline & Digital communication & 5,9 & & $\begin{array}{l}\text { Research \& } \\
\text { Technology }\end{array}$ & 19,1 & & Textiles and accessories & 31,9 \\
\hline \multirow{3}{*}{ 胥 } & $\begin{array}{l}\text { Electrical machinery, } \\
\text { energy }\end{array}$ & 9,5 & \multirow{3}{*}{$\underset{⿱ 亠}{\underline{O}}$} & Business & 12,0 & \multirow{3}{*}{$\stackrel{\frac{\pi}{g}}{\stackrel{\Xi}{\Xi}}$} & Tools and machines & 16,1 \\
\hline & Optics & 6,3 & & $\begin{array}{l}\text { Leisure \& } \\
\text { Education } \\
\end{array}$ & 12,1 & & Transport & 12,0 \\
\hline & Computer technology & 6,3 & & $\begin{array}{l}\text { Research \& } \\
\text { Technology }\end{array}$ & 20,1 & & Textiles and accessories & 17,6 \\
\hline \multirow{3}{*}{ 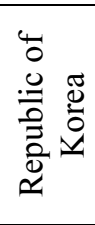 } & $\begin{array}{l}\text { Electrical machinery, } \\
\text { energy }\end{array}$ & 7,9 & \multirow{3}{*}{ 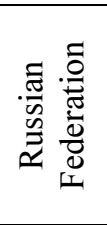 } & $\begin{array}{l}\text { Research \& } \\
\text { Technology }\end{array}$ & 12,3 & \multirow{3}{*}{$\underset{⿱ 一}{\Xi}$} & Tools and machines & 10,0 \\
\hline & Semiconductors & 7,4 & & Clothing & 13,2 & & $\begin{array}{l}\text { Furniture and household } \\
\text { goods }\end{array}$ & 15,5 \\
\hline & Computer technology & 6,4 & & Agriculture & 15,9 & & Textiles and accessories & 15,6 \\
\hline \multirow{3}{*}{$\underset{\mathscr{D}}{\mathbb{\infty}}$} & Computer technology & 14,9 & \multirow{3}{*}{$\underset{\varpi}{\mathscr{\varpi}}$} & Business & 13,9 & \multirow{3}{*}{ 希 } & Textiles and accessories & 9,8 \\
\hline & Medical tech. & 6,3 & & $\begin{array}{l}\text { Leisure \& } \\
\text { Education }\end{array}$ & 15,3 & & Advertising & 17,2 \\
\hline & $\begin{array}{l}\text { Electrical machinery, } \\
\text { energy }\end{array}$ & 6,3 & & $\begin{array}{l}\text { Research \& } \\
\text { Technology }\end{array}$ & 20,6 & & $\begin{array}{l}\text { Furniture and household } \\
\text { goods }\end{array}$ & 29,5 \\
\hline
\end{tabular}

Note: OHIM is the European Union's Office for Harmonization in the Internal Market.

Table 6. PCT, MITS and HIDS international applications by top applicants in 2014 (Source: WIPO Statistics Database, October 2015)

\begin{tabular}{|c|c|c|c|c|c|c|}
\hline Rank & Applicant & $\mathrm{PCT}$ & Applicant & MITS & Applicant & HIDS \\
\hline 1 & $\begin{array}{l}\text { HUAWEI TECHNOLOGIES } \\
\text { (China) }\end{array}$ & 3442 & NOVARTIS (Switzerland) & 281 & SWATCH (Switzerland) & 98 \\
\hline 2 & $\begin{array}{l}\text { QUALCOMM } \\
\text { (United States of America) }\end{array}$ & 2409 & $\begin{array}{l}\text { GLAXO GROUP LIMITED } \\
\text { (United Kingdom) }\end{array}$ & 234 & $\begin{array}{l}\text { PROCTER \& GAMBLE } \\
\text { (United States of America }\end{array}$ & 95 \\
\hline 3 & $\begin{array}{l}\text { ZTE } \\
\text { (China) }\end{array}$ & 2179 & $\begin{array}{l}\text { EGIS GYÓGYSZERGYÁR } \\
\text { (Hungary) }\end{array}$ & 132 & $\begin{array}{l}\text { KONINKLIJKE } \\
\text { PHILIPS (Netherlands) }\end{array}$ & 62 \\
\hline 4 & PANASONIC (Japan) & 1682 & LIDL (Germany) & 128 & DAIMLER (Germany) & 59 \\
\hline 5 & $\begin{array}{l}\text { MITSUBISHI ELECTRIC } \\
\text { (Japan) }\end{array}$ & 1593 & NESTLÉ (Switzerland) & 112 & $\begin{array}{l}\text { VOLKSWAGEN } \\
\text { (Germany) }\end{array}$ & 46 \\
\hline 6 & $\begin{array}{l}\text { INTEL (United States of } \\
\text { America) }\end{array}$ & 1539 & L'ORÉAL (France) & 94 & $\begin{array}{l}\text { SAMSUNG (Republic of } \\
\text { Korea) }\end{array}$ & 40 \\
\hline 7 & LM ERICSSON (Sweden) & 1512 & $\begin{array}{l}\text { BOEHRINGER INGELHEIM } \\
\text { PHARMA (Germany) }\end{array}$ & 92 & LENOVO (China) & 32 \\
\hline 8 & $\begin{array}{l}\text { MICROSOFT (United States } \\
\text { of America) }\end{array}$ & 1460 & HENKEL (Germany) & 90 & $\begin{array}{l}\text { GILLETTE (United } \\
\text { States of America) }\end{array}$ & 27 \\
\hline 9 & SIEMENS (Germany) & 1399 & $\begin{array}{l}\text { PHILIPS ELECTRONICS } \\
\text { (Netherlands) }\end{array}$ & 85 & NESTLÉ (Switzerland) & 25 \\
\hline 10 & PHILIPS (Netherlands) & 1391 & $\begin{array}{l}\text { WORLD MEDICINE (Tur- } \\
\text { key) }\end{array}$ & 76 & $\begin{array}{l}\text { ALFRED KÄRCHER } \\
\text { (Germany) }\end{array}$ & 24 \\
\hline
\end{tabular}


Under Hague system in TE and FH setor applications were the most popular. In Turkey and Germany we can observe also industrial design applications concentrated on $\mathrm{T}$ and $\mathrm{A}$.

In last step of research depth analysis of main applicant companies was conducted. Table 6 shows top 10 applicants around three patent systems. In PCT applicatios led Huawei Technologic company from China. This company submit 3442 applications in 2014 year. Another important user of PCT procedures was Qualcomm (USA) with 2409 patent applications.

The largest user of Madrid System was Novartis (Switzerland) with 281 applications in 2014 and Glaxo Group (UK) with 234. Those two companies was fallowed by other pharmaceutical company Egis Gyógyszergyár (Hungary). Top 10 applicants pharma, cosmetics and goods and food producing companies.

The list of top Haque system users in 2014 ranges companies that produce household, hygiene, watches, food and wehicles. He most active user in this HIDS system was Swatch company with 98 applications. Switch was followed by Procter\& Gamble and Philips Electronics. It is worth to know that the sixth main actor Samsung comes from Korea of Republic that joined to HIDS in 2014.

\section{Conclusions}

Patent statistics are a useful tool to analyze different perspectives of competitiveness on the international level. Findings of this study sugest that industry sector applicant's industries varies depending on IP type (Table 5). In this sense, the results confirmed the existance of differences at patent application level on geographical area. Leading region of the world is still the Asia. We found also important fact that on the world PCT procedures we have leaders from China and USA that submit most of the patent applications and represent the electronic industry.

Under Madrid System we can select main industry branches that are interested in IP protection - pharmacy and food producers.

This study has also some limitations. Planning the research it was noted that there were a few cases when WIPO data at required time period was unavailable. For missing data we used PATSTAT database, especially for searching indicators that are relating to patent publications by technology.

\section{Acknowledgements}

Author would like to thank the anonymous revewers for valuable comments.

\section{References}

Agrawal, A.; Bhattacharya, S.; Hasija, S. 2015. Cost-reducing innovation and the role of patent intermediaries in increasing market efficiency, Production and Operations Management 4(1): 173191. http://dx.doi.org/10.1111/poms.12391

Archambault, E.; Davis, M.; Wilson, C. S. 2001. Methods for using patents in cross-country comparisons, in Proceedings of the $8^{\text {th }}$ International Conference on Scientometrics and Informetrics, 15-19 July 2013, Vienna, Austria: 41-52.

Archibugi, D. 1992. Patenting as an indicator of technological innovation: a review, Science and Public Policy 19(6): 357-368.

Bhattacharya, S. 2007. Delineating the patent data: a case study of prolific patenting institutions of India and China, DESIDOC Bulletin of Information Technology 27(1): 87-95. http://dx.doi.org/10.14429/djlit.28.7.126

Chen, D.-Z.; Chang, H.-W.; Huang, M.-H.; Fu, F. C. 2005. Core technologies and key industries in Taiwan from 1978 to 2002: a perspective from patent analysis, Scientometrics 64(1): 31-53. http://dx.doi.org/10.1007/s11192-005-0236-9

Czemiel-Grzybowska, W. 2013. Selected constraints to development of entrepreneurship in Poland, eFinanse 10(2): 21-27. http://dx.doi.org/10.14636/1734-039X_10_2_007

Czemiel-Grzybowska, W.; Skowronek-Mielczarek, A. 2015. Entrepreneurship research in the Poland. Technological and Economic Development of Economy 21: 1-17.

http://dx.doi.org/10.3846/20294913.2015.1070770

EPO PATSTAT database, October 2015.

Johnson, B. 2015. Public standards and patent damages, Journal Marshall Review of Intellectual Property Law 14(3): 1-30.

Leydesdorff, L.; Meyer, M. 2010. The decline of university patenting and the end of the Bayh-Dole effect, Scientometrics 83(2): 355-362. http://dx.doi.org/10.1007/s11192-009-0001-6

Lisbon agreement for the protection of appellations of origin and their international registration of October 31, 1958 (as revised at Stockholm on July 14, 1967, and as amended on September 28, 1979).

List, J. 2010. An A to X of patent citations for searching, World Patent Information 32(4): 306-312. http://dx.doi.org/10.1016/j.wpi.2010.01.004

World intellectual property organization (WIPO). 1891. Madrid Agreement Concerning the International Registration of Marks. Signed on April 14, 1891 (as revised at Brussels on December 14, 1900, at Washington on June 2, 1911, at The Hague on November 6, 1925, at London on June 2, 1934, at Nice on June 15, 1957, and at Stockholm on July 14, 1967). 
Nice Agreement Concerning the International Classification of Goods and Services for the Purposes of the Registration of Marks. 1957. Signed on June 15, 1957 (as revised at Stockholm on July 14, 1967, and at Geneva on May 13, 1977, and amended on September 28, 1979).

Noruzi, A.; Abdekhoda, M. 2012. Mapping Iranian patents based on International Patent Classification (IPC), from 1976 to 2011, Scientometrics 93(3): $847-856$. http://dx.doi.org/10.1007/s11192-012-0743-4

Regulations Under the Hague Agreement Concerning the International Deposit of Industrial Designs. 1998. As in force from January 1, 1998.

Rodriguez, C.R.; Gomez, M. 2011. Innovation trends in NAFTA countries: an econometric anaysis of patent applications, Journal of Technology Management Innovation 6(3): 116-124.

http://dx.doi.org/10.4067/S0718-27242011000300009

Scellato, G.; Calderoni, M.; Caviggioli, F.; Franzoni, C.; Ughetto, E.; Kica, E. R. V. 2011. Study on the quality of the patent system in Europe. PATQUAL [online], [cited 02 January 2016]. Available from Internet: http://purl.utwente.nl/publications/76671

Schultz, J.; Urban, J. M. 2012. Protecting open innovation: the Defensive Patent License as a new approach to patent threats, transaction costs, and tactical disarmament, Harvard Journal of Law and Technology 26(1): 1-67.

Simonton, D. K. 2012. Taking the US Patent Office criteria seriously: A quantitative three-criterion creativity definition and its implications, Creativity Research Journal 24(3): 97-106. http://dx.doi.org/10.1080/10400419.2012.676974

Squicciarini, M.; Dernis, H.; Criscuolo, C. 2013. Measuring patent quality: Indicators of technological and economic value. OECD Publishing. http://dx.doi.org/10.1787/5k4522wkw1r8-en

The Hague Agreement Concerning the International Deposit of Industrial Designs. 1925. Signed on November 6, 1925 (The Hague Act of November 28, 1960).

The Hague Agreement Concerning the International Deposit of Industrial Designs. 1925a. Signed on November 6, 1925a (London Act of June 2, 1934).
The Hague Agreement Concerning the International Deposit of Industrial Designs. 1925b. Signed on November 6, 1925b (Additional Act of Monaco of November 18, 1961).

The Hague Agreement Concerning the International Deposit of Industrial Designs. 1925c. Signed on November 6, 1925c (Complementary Act of Stockholm of July 14, 1967 as amended on September 28, 1979).

unstats.un.org/unsd/ methods/m49/m49regin.htm

Van Zeebroeck, N.; Van Pottelsberghe de la Potterie, B.; Han, W. 2005. Issues in measuring the degree of technological specialisation with patent data. No. 05-016. RS, Working Papers CEB from ULB - Universite Libre de Bruxelles. [online], [cited 02 January 2016]. Available from Internet: http://econpapers.repec.org/paper/solwpaper/05016.htm.

Walicka, M. 2014. Innovation types at SMEs and external influencing factors, e-Finanse 10(3): 73-81. http://dx.doi.org/10.14636/1734-039X_10_3_006

Walicka, M.; Zemigala, M.; Czemiel-Grzybowska, W. 2015. Technology entrepreneurship - state of the art and future challenges, Eurasian Journal of Social Sciences 3(4): 10-21.

http://dx.doi.org/10.15604/ejss.2015.03.04.002

World international property organization (WIPO). 2011. International Patent Classification (version 2011) guide. Guide to the IPC (2011). Available from Internet: 02 January 2016

http://www.wipo.int/export/sites/www/classificatio ns/ipc/en/guide/guide_ipc.doc

World international property organization (WIPO). 1989. Protocol Relating to the Madrid Agreement Concerning the International Registration of Marks. (as signed at Madrid on June 28, 1989).

World international property organization, WIPO Statistics Database, May 2014.

World international property organization, WIPO Statistics Database, October 2015.

Wu, Y. C. J.; Liu, H.P. 2006. Technological innovation assessment of business-to-business electronic marketplaces, Journal of the American Society for Information Science and Technology 57(8): 10931104. http://dx.doi.org/10.1002/asi.20372 